\title{
BANKS FOR BRICS ECONOMIC DEVELOPMENT
}

\section{Yarygina Irina ${ }^{1}$}

DOI: http://dx.doi.org/10.30525/978-9934-571-28-2_28

\begin{abstract}
The article deals with important issues within BRICS international economic relations and displays the role of banks as intermediaries that supply clients with financial instruments and contribute to successful development of economic entities. Assessment of market demands of BRICS displays the necessity of the long-term financing and project management, based on transparent information flow. Common economic interests and public support back effective BRICS relationship. Expertise of the Central and Eastern European countries developments has proved that intergovernmental support and sustainable banking activity promote progressive actions in international economic relations. The results of the complex study provides a strong case for inter - banking within BRICS, which should be taken into consideration by public and private institutions while constructing economic and political approach to financial infrastructure. Economic needs and mutual interests are certainly a step in the right direction.
\end{abstract}

\section{Introduction}

Actually, BRICS economic development plays the key strategic role in its banking and finance. There is no denying the fact, that effective banking strategy depends on accurate assessment of common problems and a search for mutual solutions to increase quality of life in member countries.

From the European experience, fast liberation of financial-economic relationships leads to decline in some areas of economy, including strategically important ones, and to slowdown of government regulation of key industrial areas, which leads to increase of bank speculations and high-risk level of economic environment. To find the way in turbulence is the main task for the government that has to use different vehicles, intergovernmental monetary and fiscal measures including.

${ }^{1}$ Doctor of Economic Sciences, Professor,

Professor at Department of World Economy and World Finance, Head of Programs,

Financial University under the Government of the Russian Federation, Russian Federation 


\section{Banks for brics economic development}

\section{Literature review}

The theory of fiscal federalism identifies main functions for the public sector: macroeconomic stabilization, income distribution and resource allocation(Oates, 1999) [1]. The problem of fiscal decentralization in developing countries are carefully studied by Fukasaku and de Mello (1999), Manor, Crook and Manor (1998-1999), that tried to give reason to the restructuring of government and market functions. Some scholars within the public choice school consider that decentralization tends to increase competition among jurisdictions (Brennan and Buchanan, 1980; Breton, 1989). Anyway, in globalized economy developing countries (Ahmad, 1997) require the mechanism of intergovernmental grants transfers. Thus, the intergovernmental financial institutions can contribute to it, supplying the country-members with unconditional, conditional and equalization grants (Brosio, 2000).

There is no denying the fact, that only international experience can provide useful methods for policy makers (Bird and Vaillancourt 1998), but the approach of laissez-faire or market fundamentalism has a week potential to solve most economic and social problems (Stiglitz, 1998). Market fundamentalism was popularized by George Soros in "The Crisis of Global Capitalism" (1998) with its trust in a free market mechanism. That is a privilege of a genius, but practice has proved the approach of J. E. Stiglitz, who criticized the IMF, advocating a set of policies, which is generally referred to the market fundamentalism, "based on an incorrect understanding of economic theory and as an inadequate interpretation of the historical data." The correct understanding means reasonable regulation and cooperation in solving mutual problems and meeting new challenges. There is an on-going process of reengineering international cooperation within globalized economic environment. The speed of cooperation depends on macro and microeconomic factors, as well as participation in the global market, supply of the products and political support. Mutual aims of any government are linked with economic and social developments, as well as successful production, safe banking, financial stability and effective debt management that is the main feature of globalization. The goals can be reached within BRICS cooperation.

\section{Research methods}

The study of financial institutions' role within BRICS is based on complex research methods, based on gathering and analyzing data, needed 


\section{Yarygina Irina}

to answer the research goal. Mostly used were qualitative and mixed methods. Within these categories, more specific approaches, including an array of options, case studies, self-reporting and surveys were applied. The mixed methods of research, that included contextual understanding like interviews or observations, were combined with facts and statistics, that contributed to the investigation of the subject on multiple levels, gaining different views and a comprehensive look at the research, An applied mixed methodology led us to the integration of different theories and ideas. While carrying out the qualitative research, there was a goal to explore specific phenomena, not to prove a prediction, according to qualitative research methods. The assessment of interviews, focus groups and observation of main developments and contract arrangements were also used to collect data. Used qualitative methods provided rich, contextual explorations of the topic that is culturally meaningful.

\subsection{BRICS banking}

\section{Research results}

BRICS developing economies play a special role in contemporary world. They are characterized by a dynamic development, which is particularly important in situations of post-crisis development. BRICS have advantages in economic activity which is distinguishing them from the other countries, including big human potential; vast reserves of natural resources (water, forest, bio-resources, minerals, energy, etc.); large domestic market, etc. Financial markets are of particular importance for the development of the economies of the BRICS. They has constantly improved, actively developing. Experts believe that in the near future due to the growth and development of financial and credit institutions of the BRICS the world economy and stock markets will grow rapidly. In this regard, of particular interest is the banking sector. On the form of ownership of the banking sector introduced the BRICS by private banks, public (which occupy leading positions on deposit and loan transactions), as well as banks with foreign capital.

In Brazil there are about 180 private commercial banks. One third of these banks have deposits of more than 100 billion. dollars. United States. Along with commercial banks operate about 30 commercial government development banks and public banks, savings and loans, investment banks and 20 others. A key part of Brazil's banking system is the Banco Central 


\section{Banks for brics economic development}

do Brasil (Central Bank of Brazil), founded in 1808. It is considered to be the oldest Bank in Brazil and one of the oldest in Latin America. The Bank is a company with mixed capital, $68.7 \%$ of shares belongs to the Federal Government of Brazil. The Bank's shares are traded on the San Paulo Stock Exchange. Currently, the Bank has 9200 branches in Brazil and 32 representative offices abroad. The size of Banco do Brasil's assets exceeds $17 \%$ of banking assets in the country. Federal Savings Bank (Caixa Economica Federal), founded in 1861, is the second largest bank in the country at the $100 \%$ owned by the state. The third position is held by Bradesco Bank, founded in 1943. Currently the Bank is one of the largest banks in Brazil. The Bank Bradesco offers its customers a wide range of banking operations and services in Brazil and abroad. Ten largest banks in Brazil include have assets over 100 billion dollars. The State controls 10 Brazilian banks, 6 of which are owned by the Federal Government and the 4- Governments of states. Under the supervision of the State are the biggest credit institutions (in particular, Banco do Brasil and Caixa Economica Federal), while the others run by private capital-Brazilian and foreign.

Russia since 1987 has a two-tier banking system provided by the Central Bank of the Russian Federation (Bank of Russia) and credit organizations. In April, 2017 the State Duma adopted the Federal law on the division of banks of the second level of banking system: a) with the base license and b) banks with universal license that allows commercial banks to carry out a specific (under license) a list of banking operations and services. The Bank of Russia is implementing now a differentiated supervision of these banks in accordance compliance with prescribed obligatory standards of banking activities. In Russia prevail joint-stock commercial banks: a) the state-controlled banks); b) controlled by foreign capital; c) major private banks; d) medium and small regional banks. The number of state-controlled banks include: Sberbank (Savings bank), VTB, Rosselkhozbank (Russian agricultural bank), Gasprombank, etc.

Over the past 10 years (from 01.01.2007 to 01.01.2017) number of Russian banks has fallen almost doubled from 1143 to 575 . At the same time:

- the proportion of top-5 banks in total assets increased from $42.5 \%$ to $55.3 \%$ (a percentage of banks with 201 seats and below dropped from $8.2 \%$ to $2 \%)$; 
- the ratio of large credit risks to the capital remained almost unchanged (240.6\% and became 236.3\%);

- capital adequacy has declined from $14.9 \%$ to $12.7 \%$; return on assets fell from $3.2 \%$ to $0.9 \%$;

- the percentage of credit as a source of capital investment fell from $8.7 \%$ to $5.9 \%$;

- asset dynamics completely unfolded: with $+43.3 \%$ to-3.5\%;

- the proportion of established reserves for possible losses increased from $3.2 \%$ to $7 \%$ of the total volume of banking assets.

The state-owned banks account for the major proportion of the total banking assets (about 50\%)/ These credit institutions occupy a significant share of the market of bank services. In particular, according to the Central Bank of Russia, at the beginning of 2017, they accounted for about $45 \%$ of all deposits and other borrowed funds of companies and $70 \%$ of deposits of the population. Now about 100 banks, controlled by non-residents operates in Russia. They have $25 \%$ of all bank assets. This is mainly credit institutions with $100 \%$ foreign participation. A total of 136 large private banks. The most numerous group-medium and small regional banks. But despite their dominant numbers, they occupy a modest place in the banking sector, focused $5.4 \%$ of all assets, about $3 \%$ of the deposits of enterprises and organizations, $7 \%$ of deposits and loans to corporate borrowers and to the population, make up less than 5\%. Russia's banking sector for a number of reasons the macroeconomic and national level (including the change of economic formation in the 1990-ies, the successive economic crises (1998, 2005), the global banking crisis 2008-2010, Ukrainian and Crimean crisis (2013-2014) and subsequent sectoral sanctions) is behind in the development of the leading countries in Western Europe and the United States as well as China, India and Brazil. A key issue for the development of the Russian banking system is the slow growth of GDP in Russia, the country's sovereign rating, low volatility in the financial markets and a high level of risk.

India operates a two-tier banking system. The first level of which is the Central Bank - Reserve Bank of India. It manages the public debt of the Central Government and State Governments, holds hard currency reserves of the country and oversees the repatriation of export proceeds, the return of invested capital abroad for investments inside its country and payments for imports. Reserve Bank provides short-term loans to State Governments and 


\section{Banks for brics economic development}

registered banks, and provides short-and medium-term credit to cooperative banks in the states and to financial and industrial institutions. The banking sector of India includes commercial, cooperative, regional rural banks and non-bank financial institutions. Commercial banks are divided into state-controlled, private and foreign. Of commercial banks $27 \%$ are statecontrolled, 30\% private banks and $40 \%$ are foreign. In India there are restrictions on the participation of foreign capital in Indian banks. Nonresident shareholders may have up to $74 \%$ of shares. Currently, ICICI Bank, which controls a quarter of the entire market of banking services in India, $68 \%$ of shares are owned by non-residents. For the state banks of India the proportion of foreign shareholders is limited and may not exceed $20 \%$. State-controlled banks dominate the banking sector in India, they account for about $75 \%$ of assets, $79 \%$ of deposits, $78 \%$ of loans, $79 \%$ of banking capital. State banking sector comprises 28 credit organizations, led by State Bank of India (State Bank of India, SBI). On the sizes of the leading Indian banks are not inferior to the world-class banks. India currently operates 36 foreign banks, as well as 68 corporate banks (small companies serving predominantly farmers, artisans and small entrepreneurs; issue is usually short-term and medium-term loans).

China's banking system is represented by the Central Bank, banks for special public funding, state commercial banks, joint-stock banks, city commercial banks and non-banking financial institutions (urban and rural credit cooperatives, trust investment companies). Credit institutions for public funding are specialized banks, that should support economic policy of the Government. Among them there are China Development Bank, Export-Import Bank of China and Agricultural Development Bank of China. Through them, the State allocates funds to stimulate the development of priority sectors or objects. There are four largest bank in China with the state capital: the Bank of China (Bank of China), Industrial and Commercial Bank of China (ICBC), the Agricultural Bank of China and China Construction Bank (CCB). More than 10 joint-stock commercial banks were opened in China mainly by enterprises on a mutual basis. In most cases, a majority stake is owned by the State, represented by the Government agencies or state enterprises.

Total assets of the commercial structures represent $15 \%$ of the total banking assets. The main objective of urban commercial banks issuing loans to support and develop local infrastructures. Similar financial institutions 
exist only in major cities (Shanghai, Beijing, Zhengzhou). There are more than 100 urban cooperative banks or urban commercial banks in China, whose activities are limited to these cities. Their total assets account for $10 \%$ of all bank assets. These credit unions have a long history and have developed branch network in China and a large number of affiliates abroad. Other financial institutions include urban and rural credit cooperatives, rural commercial banks, investment, finance and credit trust companies, foreign banks and others. The non-bank institutions segment occupies a significant place in the financial markets of China, there are more than 36 thousand (they accounted for $27 \%$ of all bank assets).

The pillars of the banking system of the Republic of South Africa can be attributed to South African Reserve Bank (Central Bank), commercial banks and specialized financial institutions (the State Development Bank of Southern Africa (financing of infrastructure projects in the region SADC (the Southern African development community), the Industrial Development Corporation (industrial projects), Land and Agricultural Bank (agricultural lending). The banking system of the Republic of South Africa is well developed and effectively regulated. In recent years, many foreign banks and investment companies began to work in South Africa. In South Africa operates: 17 registered banks, 3 credit union banks, 1 cooperative bank and 14 branches of foreign banks. Major banks in South Africa are: ABSA (Absa Group Limited), FirstRand Group, FNB (First National Bank), Standard Bank Group, South African Reserve Bank. ABSA (Absa Group Limited) is one of the leading financial groups in South Africa, formed in 1991; the Bank serves more than 11.7 million customers and is a division of Barclays Bank from 2005, 55.2\% of shares belongs to the group. FirstRand Group (founded in 1988) has assets of more than 125 billion dollars, provides investment banking, asset management, wealth management and advisory services. FNB (First National Bank) is the oldest South African Bank, founded in 1838. It is part of the "big four" banks in South Africa and has branches in Mozambique, Botswana, Namibia, Swaziland and Zambia. Currently is a division of FirstRand Group. Standard Bank Group (Standard Bank) from 1862 is the largest bank in South African Republic in terms of assets and profits. The Bank operates in 33 countries around the world, including 17 African countries and has more than 600 offices in South Africa and more than 400 outside the country within the continent. The Bank employs over 50 thousand employees worldwide, of whom about 


\section{Banks for brics economic development}

35 thousand are in South Africa. South African Reserve Bank is the Central Bank of South Africa established by Parliament in 1921. The primary function of a bank is to provide financial stability for the achievement of sustained economic growth in the country.

Analysis of BRICSvnational banking systems allows to draw some conclusions. Firstly, all BRICS countries are characterized by significant government involvement in the banking sector. The largest banks that define the state and development of banking systems of BRICS are under the control of governments. This feature allowed BRICS credit institutions to overcome global financial and banking crisis 2007-2009 easier than the developed countries.

Secondly, it is clear that different scales, structure and degree of involvement in transnational activities on the world markets characterize these countries' banking systems.

\subsection{BRICS banking facility}

Research proves that banks of emerging markets are in a race towards "fast profits" and cut down on traditional operations (project financing, loans, etc.). Vast amount of operations is attributable to expatriation of capital into offshore zones. According to the World Bank, absence of banking support for economic development in ex-USSR countries lead to manufacturing decline of $65 \%$. However, in countries with government involvement and gradual market transformation - economy recovered faster (Belorussia, Kazakhstan, Uzbekistan). Use of reasonable government regulation of economy, as a whole, is a vital condition of development and formation of new approach to the realisation of commercial relationships and aids development of international banking. Effective cooperation between participants of BRICS countries is also influenced by the amount of government support given to economy during formation of market relationships. Under growing economic co-operation manufacturing feel pressure from their clients that require quality goods and services and from competition, which are able to offer better quality at a lower price. Sensible regulation of inter-state relationships encourage economic co-operation. In its tern, creation of common legislation base, which provides effective banking servicing of BRICS economy, will create stable foundation for collaboration. Establishment of essential conditions for interaction between credit institutions requires time and political power. The analysis 
of current developments of emerging markets has proved that banks are able to support economy sectors during growth of partnership by backing economic interest of countries and encouraging trade development that increases cooperation. Banking support for the least protected market participants - SMEs, entrepreneurships - driver and buffer of any economy will create favourable conditions for effective economic operations, creating employment, production of goods that are under market demand.

Effective global cooperation of BRICS countries connected with necessary design of common banking support strategic developments. Consequently, creation of a reasonable international strategy is possible by using holistic analysis of economic demands of each member-country. Reality has shown that absence of economic forecasting in banking activity leads to negative consequences. For example, "tax holiday" policy, granted to banks by state of Brazil when dealing with foreign investors caused overproduction of cars, which created stagnation of number of economical segments.

According to the European experience, it is important to provide legal coverage for property of economic partners - a key business component taking into consideration specifics of each country.

Formation of mutual economic strategy increases importance of banking intermediary, especially in the area of financial risk management, liquidity financing and management of financial capital. Country's economic development depends on the level of banking business involvement, attributable to customers and market partners.

Rating of market demands of BRICS shows that implementation of joint growth programme demands long-term financing, project financing, inclusive of syndicates and constant information flow in all segments of economy. Effective relationships between entities are built on foundation of common economic interests and governmental support. Expertise of many countries from Central and Eastern Europe has proved that public support and substantial banking activity desire to minimise change and promote progressive actions in restoration of economic ties.

During the formation of a mutual economic strategy, it is important to consider the experience of CEE countries, which overcome the consequences of market reforms in the economy, which showed that countries are not concerned with prospect of banking reform but how they are going to be implemented in reality. In this regard, presence of 


\section{Banks for brics economic development}

objectivity in progressive actions towards available financial resources is very important. Governments support of entrepreneurs who are dealing in area of international trade, unification of banking activity and policies will create favourable conditions for economic cooperation within BRICS.

Growth of economic ties of member-countries based on common values and development goals suggests a long-term strategic alliance of private credit institutions in the field of international trade, taking into account customer flexibility. Sound financial management, modernisation of banking technology will also contribute to the development of the BRICS market.

Support of the balance of interests of public and private structures, growing capacity of joint investment financing, strengthening the legal framework and improving the legal support of business - processes contributes to the development of economic cooperation of economic entities. In addition, banks' activities supporting economic cooperation among BRICS countries should be transparent and accessible to the customer, regardless of the place of accreditation if their business activities executed in the economic environment of these countries.

One of the important directions of banks - participants of international economic cooperation is a support programme of trade relations ("Trade Finance Promotion"), which assists customers in selecting contractors for International Cooperation.

Actually, small and medium-sized enterprises of BRICS membercountries have to apply adverse cooperation schemes, including an advance payment for imports. In other cases, the completion of foreign trade contracts is prevented by excessive pricing conditions for underwriting and insurance payments. In this regard, using interstate status, a number of banks members of the BRICS can help to achieve favourable agreements with banks - exporters to improve the conditions for international cooperation.

One of the most important trends of banks is to provide payment guarantees to exporters, ensuring pre-export financing and cooperation with insurance companies. It seems appropriate for BRICS international banks to move towards the development of special operations primarily related to export - import activities of economic entities and to provide customers and their counterparties with a variety of banking services on the agreed "flexible" terms of cooperation.

Namely, it can be provision of documentary operations, organisation of the bank syndicate to finance exporters / importers, financial market 
transactions, advising stakeholders during contract finalisation. Banks can also assist clients in calculating the limits for dealings with exporters and importers, confirmation of letters of credit and guarantees, issuance of guarantees and counter-guarantees, use of intergovernmental opportunities, taking into account documentary instruments, promissory notes, drafts, etc.

In order to maximise demand of economic entities, BRICS banks are expedient to: acceptance of drafts drawn by exporter / importer, financing exporters against documentary letters of credit, provision of agreed overdrafts, insurance of credit lines for exporters / importers, financing of drafts drawn by exporters, financing of collection documents with recourse to the borrower, provide trade financing against contract documentation. Financing of goods supply in the initial stage of the implementation of contracts (for up to 180 days), financing of importers/exporters, financing of the fulfilment of contractual obligations, financing documents against acceptance, implement pre-export funding are of an interest to BRICS banks' clients.

It is worth, while mentioning, that BRICS balance of payment specificity contributes to cooperation, based on national currencies, namely: clearing payments and services, multicurrency accounts facilities, with the possibility of strengthening account liquidity in national currencies from the surplus balances and manage clients' short-term liquidity, as well as management of accounts through mutual telecommunication system, maintain escrow accounts, etc.

Considerable attention is to be payed to corporate clients and consultancy on monetary and financial conditions and payment of export-import contracts in national currencies, as well as to BRICS currency regulation and control. Administration of short and medium term financing, transactions in national currencies, syndicated loans, currency risk management, provision of trust operations in national currencies and other currencies on behalf of BRICS banks clients can be of an interest to consumers.

An important component of creating a common economic space for BRICS countries is a presence of an intergovernmental insurance programme with participation of intergovernmental agencies for export insurance and guarantee of international operations. Specialised agencies of BRICS are able to promote effectively multilateral cooperation of business partners.

Banks involvement in encouraging formation of joint leasing companies with the public support also contributes to international relations. An important area of governments - sponsored cooperation is financing of 


\section{Banks for brics economic development}

innovative and knowledge-intensive projects, as well as socio - economic programmes: environmental protection, infrastructure development, energy - supply and health programmes, etc. At the same time, an important activity of BRICS banks can be linked with modernisation and engineering support of innovations, as well as in supporting joint credit lines in order to ensure the economic benefits and enhance the living standards of citizens of BRICS countries - members. In turn, the formation of the multilateral clearing system stimulates the development of BRICS' payment system. At the same time, BRICS monetary cooperation ameliorates the global financial infrastructure and makes it more reliable.

\subsection{Priorities for BRICS banking}

Currently, the main priority of the BRICS group is the formation of a common currency and investment reserves, as well as the development of mutual settlements in national currencies, that involves not only the currency instability on world markets, but also because many states out of BRICS want to develop business ties with the countries of this group. This, in turn, necessitated the establishment of the General monetary reserve and the BRICS Investment Bank in conjunction with the development of mutual settlements in national currencies and the need to increase competitiveness. BRICS have initiated a number of global proposals aimed at strengthening the stability of world financial markets, including the creation of BRICS New Development Bank, BRICS Reserve Monetary Fund, Insurance Pool, Exchange Alliance, etc. The creation of BRICS New Development Bank is a key to the successful development of the real sector of economy and further industrialization of BRICS. One of the priority objectives of any Bank is to provide systemic support to medium and small businesses, as well as public sector organizations and enterprises under the privatepublic partnership. These projects benefit all member countries of the group. Declaration on the New Development Bank establishment with a capital of $\$ 100$ billion is signed by the member countries in 2014. It is expected that the Bank may become a rival to the World Bank and other international and intergovernmental financial institutions. Currently, the New Development Bank mainly specializes in infrastructure projects in the territories of the member countries. The first President of the Bank became the representative of India. And its headquarters is located in Shanghai. In recent years, the Development Bank of the BRICs (and worldwide) is 
being actively discussed the problem of "bad debts", which is impossible without post-crisis recovery, sustained growth and development of BRICS credit market. Among the urgent problems which are to be resolved - the crisis of confidence that must be overcome together, otherwise enterprises will continue to make problem debts. In the expert community there are consultations on establishment a multilateral information system, similar to SWIFT. BRICS Finance Ministers and Central Bank Governors are discussing the whole range of issues, including setting up a clearing system and transition to payments in national currencies. The purpose of establishment of such a system is to convey sustainable clearing for BRICS.

\section{Analysis and discussions}

Actually, BRICS market participants assess the role of public institutions in modern economy: either it is a "pilot star" of the risky market or a bureaucratic vehicle, that enforces economic entities for non - profit behavior. What is it? EU has given examples of a reasonable contribution of governments to economic progress. The experience of countries, bridged over transformations, pushes forward the idea of fruitful correlation of public and private entities, achieving economic development and profitable activity. Actually, the government of the Russian Federation is keeping the way of economic supervision, not for the sake of reforms but in order to improve standards of living. Starting from the nineties of the XX century Russia entered the period of reforms. Within next fifteen years the market economy and its transparency has been growing. During the period of 2000-2007 standards of living have been improved as a result of a reasonable state participation in economic developments. International experience has been approved in the countries of the Central and Eastern Union:

1.Uncontrolled market (1991-1999) has brought the country to social tension, polarization and unemployment. Based on international experience reasonable measures has contributed to the positive effect on price formation and structure of the economic development. The world economic crisis has also proved the hypothesis of the predominate role of the state in regulation of the market economy.

2. Market participants are doing their best in achieving short-term results, guided by "selfish" demand of profit, that sometimes contradict the socio economic interest. Thus, it is impossible to back totally on the "wheels" of the market. 


\section{Banks for brics economic development}

3. Spontaneous change of the market economy is linked with financial discrepancies and accompanied by systemic and functional risks. To ensure social demand under these circumstances public institutions cannot, but support private entities to manage risks.

4. Public supervision does not mean involvement into activities of private entities - intention is to challenge society interests, such as:

- economic growth, production increase, development of innovations, improvement of supply and demand structure;

- decrease of unemployment rate, support of price level;

- social responsibility: respect of regulation and profitable activity within the market environment.

There is no denying the fact, that the challenge of any government is the efficiency of macroeconomic supervision, provision of flexible rates for the economic growth, improvement of legislation, unification of business standards and increase of living standards. Main problems to be solved by any government are the insurance of economic development; stimulation of public private partnership; reasonable regulations. Actually, developing countries are adopting to international standards, taking into consideration current economic environment that contributes to easy BRICS business contacts. To ensure positive developments the countries adopt laws of the market development and its supervision that protects economic entities make their activity transparent. New challenges for public and private entities within the market are linked with responsibility of its activity: financing and insurance of export credits, production/promotion of goods and services, intellectual property and innovations. BRICS private entities take into consideration the international experience: special attention is paid to the early European capitalism in Germany, for example, that has proved the effectiveness of a centralized control over prices, quality of goods and services, tax and rates regulation. The historic "merry-go-round" produces lessons that should be put into local environment in accordance with its specificity. For example, there is a variety of proportion of monopolism and liberalism in different states and sometimes the necessity of state regulation of economy is considered to be doubtless. At the same time, the succession of economic cycles shows that self-curing of the recession is impossible without public finance involvement. More than that, during the crisis the ties between the state and its entities deepens. Within the economic breakdowns or sustainable development, any state bears responsibility for its economic 
and social background. Public authorities have a vast range of instruments to influence the situation: taxation, monetary policy, legislation, etc. For example, the government of the countries of Central and Eastern Europe pay great attention to implementation of efficient fiscal policy initiating the economic growth, such as: state expenses on social programs; maintenance of strategic development; reasonable taxation. The main challenge of the governments is to improve living standards, backed by the steady economic growth. An important role in providing financial support play financial intermediaries. At the same time an efficient banking strategy depends on the adequate estimation of economic peculiarity of its clients. European experience shows that speculative banking activity leads to great problems: cutback of production, abrupt economic deregulation, etc. Being in pursuit of fast earning, private banks often cut down traditional banking and capital outflow to offshore zones. Reasonable regulation and supervision of the banking sector helps to reinstate economic background that is reinforced be international cooperation. At the same time, efficient international cooperation of private and public entities depends on instruments of economic and financial support. There is no denying the fact, that market participants are under pressure of client's demand of high quality goods and services and the competitors are able to offer consumers goods of a better price and quality. Under these circumstances, equal treatment of all market participants and transparent determination of general principles of activities can push forward international cooperation. Unified legislative base, efficient bank support of economic entities creates steady background for regional cooperation within the integrated economic area. However, formation of effective conditions for cooperation takes time. In general, underdeveloped countries are too enthusiastic and they underestimate the period of adoption to the level of the industrial growth. At the same time, some researches point out the lack of a "political will" that usually spoils the situation. Actually, it reveals through economic sanctions that are not productive for the market participants.

EBRD experts conclude, that, for example, the some of the CIS members are facing considerable decline of standards of living. This fact requires immediate action within the programs of international economic cooperation of the countries that have deep economic and cultural roots. Some of the post-soviet countries are suffering from bankruptcy, merges, acquisitions, lack of resources, etc. Solid banking support can help to 


\section{Banks for brics economic development}

recover. Regional programs of public support of non-protected participants of the market - small and medium enterprises (SME), for example, create favorable conditions for enterprises, capable to reach economic goals with public support. Unification of financial and banking rules helps to implement efficient support of SME's activity and effective international cooperation is connected with the unanimous international banking strategy. Putting it into action depends on a complex analysis of economic demands and challenges of market participants. The analysis confirms also, that there is a stable tendency within the emerging financial markets: mergers of institutions, based on different motives. In general, the possibility of future profits is the most common motive for a merger. Firms will perform certain measures if it is the most profitable way of enhancing capacity, entering new product or geographic areas, acquiring new knowledge or skills, or reallocating assets into the control of the most efficient managers or owners. International experience suggested motives for mergers and acquisitions include efficiencies, financial and tax benefits, market power effects, management greed, obtaining a good buy and stakeholder expropriation. In terms of efficiencies firms and banking institutions of BRICS can combine their operations through mergers of firm's/bank's assets in an effort to reduce production costs, increase outputs, improve product quality, acquire new technology and/or produce new products. Aside from the new and improved products and output possibilities, mergers can create a market for corporate control that can safeguard against inefficient management. This can be made possible by reallocating resources from firms with inefficient management to firms with efficient management especially in turbulent ages. This helps to keep profits stable and reduce the risks. Another wellknown motive refers to is stakeholder expropriation where shareholders gain at the expense of stakeholders. An example of this would be if a firm is looking to be acquired in order to escape financial problems or to back out of unfavorable labor contracts. One of the basic motives for BRICS mergers is the consolidation of ownership. In advanced market economies, this can be seen through takeovers in Central and Eastern Europe. There is no denying the fact, that takeovers help to solve corporate governance problems and due to the merger, the firm values actually increases in the process, suggesting that profits may increase afterwards. An important factor of mergers is that they require a liquid capital market in order for the bidder to have access to large amounts of capital in the short term in order to 
manage it in common interests. The only one thing worthwhile mentioning: acquisitions and mergers announced in a hot merger market can end up having declines in the bidder's stock price in the end. This can be tempting for managers to make bad acquisitions if they are rewarded with short-term performances. Sustainable banking activity and their support of BRICS economic entities will also expand the economic ties.

\section{Conclusions}

The results of the study provide a strong case for banking support of BRICS economic developments, which should be taken, into consideration while creating mutual approach to the restructuring of global infrastructure. Economic needs and mutual interests are certainly a step in the right direction of cooperation. However, setting and meeting the needs depend on banking and finance. It is also recommended to take into consideration the international experience and to introduce the required instruments and harmonized regulation for BRICS banking. Presented results of the study can benefit regulators and banks by providing new vehicles for BRICS economic cooperation.

A further novel concept introduced in this study is the use of techniques to distinguish between short-term and long-term relationship and to formulate corporate strategy, based on real requirements of economic entities. The concept can be generalized in future studies of BRICS and their entities in assessing probabilities and the ways of cooperation.

Finally, insight is provided into how mutual interests affect banking and BRICS economic goals.

\section{References:}

3. Ahmad, E. (1997). Intergovernmental transfers - an international perspective, chapter 1 in Ahmad (ed.) Financing decentralized expenditures. An international comparison of grants. OECD Publishing, http://dx.doi.org/10.1787/5k9csfs90fr4-en

4. Bird, R. \& Vallencourt, F. (1998). Fiscal Decentralization in developing countries. Cambridge: Cambridge University Press. https://www.cambridge.org/ core/services/authors/journals.pdf

5. Brennan, G. \& Buchanan, J.M.(1980).The power to tax: Foundations of a fiscal constitution. New York: Cambridge University Press. http://oll.libertyfund.org/ titles/buchanan-the-collected-works-of-james-m-buchanan-vol-9-the-power-totax.pdf

6. Breton, A. (1989). The growth of competitive governments. Canadian Journal of Economics, vol. 22. http://onlinelibrary.wiley.com/doi/10.1111/caje.12281/abstract 
7. Brosio, G (2000). Decentralization in Africa. The African Department. Washington DC: International Monetary Fund. https://www.bookstore.imf.org/ books/title/collapse-and-revival?redirected=true.pdf

8. BRICS and Africa (2013): partnership for development, integration and industrialization Collection of information and analytical materials on the theme of the Summit of the BRICS 2013 in South Africa. http://www.unido.ru/upload/files/s/ sbornik_pic.pdf.

9. Crook, R.C. \& Manor, J. (1998). Democracy and decentralization in South Africa and West Africa. Participation, accountability and performance. Cambridge: Cambridge University Press. ttps://books.google.co.uk/books?id=4Xn3c7X-xk$\mathrm{kC \& printsec}=$ frontcover\&hl$=\mathrm{ru} \&$ source $=\mathrm{gbs} \_\mathrm{ge} \_$summary_r\&cad $=0 \# \mathrm{v}=\mathrm{onep}-$ age\&q\&f.pdf

10. Fukasaku, K. \& L.de Mello Jr. (1999), Fiscal decentralization in emerging economies. Governance Issues. Paris: OECD, Development Centre. http://unpan1.un.org/intradoc/groups/public/documents/UNTC/UNPAN018217.pdf

11. Oates, W. (1999). An essay on fiscal federalism. Journal of Economic Literature, vol.37, no.3 http://econweb.umd.edu/ oates/research/fiscalfederalism.pdf

12. Russian Federation: Financial Sector Assessment July 2016 [Electronic Resource] / The World Bank, 2016 - p. 10. Mode of access: http://documents. worldbank.org/curated/en/936001472672149654/pdf/Russian-FederationFSA-07272016.pdf.

13. Shavshukov, V.M., Developing markets in the BRICS in global finance system/V.M. Shavshukov//Vestnik St. Petersburg University. - 2012. No. 5 (1). S. 119-136.

14. Soros, George (1998). The Crisis of Global Capitalism: Open Society Endangered. New York: Public Affairs. ISBN 978-1-891620-27-0 https://www.amazon.com/Crisis-Global-Capitalism-Society-Endangered/dp/ 1891620274

15. South African Banks [Electronic Resource]. - 2014. - Access mode: http://www.wbanks.ru/africa/south-africa.html. Access date: 01.11.2014

16. Stiglitz, Joseph (1998). Redefining the Role of the State - What should it do? How should it do it? And how should these decisions be made? Paper presented at the Tenth Anniversary of MITI Research Institute, Tokyo. http://people.ds.cam.ac.uk/ mb65/library/stiglitz-1998.pdf 